\title{
Carbon Stock Variation Along Altitudinal Gradient of Wacho Forest in Hawa Galan District, Kellem Wollega Zone, Oromia Region, Ethiopia
}

Gezahegn Gashu ( $\sim$ gezahegngashu2009@gmail.com )

University of Gondar

Gebre Gidey

Dambi Dollo University

Sime Deressa

Dambi Dollo University

Zame Fekansa

"University of Phoenix"

Halid Awoke

Dambi Dollo University

Research

Keywords: Wacho forest, Carbon stock, Altitudinal gradient

Posted Date: June 18th, 2020

DOl: https://doi.org/10.21203/rs.3.rs-33688/v1

License: (9) This work is licensed under a Creative Commons Attribution 4.0 International License.

Read Full License 


\title{
Carbon Stock Variation along altitudinal gradient of Wacho Forest in Hawa Galan District, Kellem Wollega Zone, Oromia Region, Ethiopia
}

Gezahegn Gashu ${ }^{1}$, Gebre Gidey $^{2}$, Sime Deressa $^{3}$, Zame Fekansa $^{4}$, Halid Awoke ${ }^{5}$

${ }^{1}$ Department of Natural Resource Management in college of Agriculture and Environmental Science, University of Gondar, Ethiopia

${ }^{2}$ Department of Natural Resource Management in college of Agriculture and Veterinary Medicine, Dambi Dollo University, Ethiopia

${ }^{3}$ Department of Natural Resource Management in college of Agriculture and Veterinary Medicine, Dambi Dollo University, Ethiopia

${ }^{4}$ Department of Natural Resource Management in college of Agriculture and Veterinary Medicine, Dambi Dollo University, Ethiopia

${ }^{5}$ Department of Natural Resource Management in college of Agriculture and Veterinary Medicine, Dambi Dollo University, Ethiopia

Corresponding Author's email address: gezahegngashu2009@gmail.com

\begin{abstract}
Background: Forest ecosystem plays a crucial role in the global carbon cycle; as such, mitigating high atmospheric concentrations of carbon dioxide and other greenhouse gases by naturally taking carbon from the atmosphere through photosynthesis. Verification and accounting of carbon stock in forest ecosystem have been renowned as a potential strategy to reduce and stabilize atmospheric concentrations of greenhouse gas. Forest sequesters and store more carbon than any other terrestrial ecosystem and it is an important natural break on climate change. It acts as a carbon reservoir by storing large amount of carbon in trees, undergrowth vegetation, forest floor and soil.

Result: The mean carbon stock of each carbon pool was changed along altitudinal class of the study area. The largest mean above and below ground carbon stock was found in the second altitudinal class(1560.01-1643m) followed by first altitudinal class(1435-1560m) and the third altitudinal class (1643.01-1704m) of the study area. The largest mean dead tree and dead wood carbon stock was also stored in the first altitudinal class followed by the third and the second altitudinal class of the study area. The largest mean litter carbon stock was found in the first altitudinal class followed by the second and the third altitudinal class of the study area. The largest mean soil organic carbon was found in the third altitudinal class followed by the second and the first altitudinal class of the study area.
\end{abstract}


Conclusions: The carbon stock variation along altitudinal gradients indicated that, altitude had no a statistically significant effect on any of the carbon pools except litter carbon of the study area at $95 \%$ of confidence interval.

Key words: Wacho forest, Carbon stock, Altitudinal gradient

\section{Background}

The carbon stock of forest is impaired by deforestation and forest degradation, which results the release of carbon dioxide to the atmosphere [13]. This increases the concentration of Greenhouse gases (HGs) in the atmosphere, which is documented as the leading cause of human induced global climate change [15]. Carbon dioxide is the major greenhouse gases, which accounted about $60 \%$ of the global warming that projected to increase the world temperature [10]. In Africa, deforestation accounts nearly $70 \%$ of the total greenhouse gas emission [5]. The clearing of tropical forest destroys globally important carbon sinks that are currently sequestering carbon dioxide from the atmosphere, and which are critical for future climate stabilization [22].

Climate change and anthropogenic stress factors are accelerating the rate of tropical forest degradation and increasing carbon dioxide emissions [8]. The trees and forests of Ethiopia are under tremendous pressure because of the radical decline in mature forest cover and the continual pressures of population increase, inappropriate farming techniques, land use competition, land tenure, forest modification and forest conversion [25]. The ecosystem services that can be generated from the dry Afro Montane forests of Ethiopia are threatened mainly by anthropogenic pressures, including extensive forest resource utilization and land use changes [24]. The government of Ethiopia has developed Climatic Resilient Green Economy since 2012 aimed at keeping the greenhouse gas constant and makes the country carbon neutral by 2025 by applying abatement measures in different sectors of the country like forestry, agriculture and industries [16].

Even though, Ethiopia does not have carbon inventories and databank to monitor and enhance carbon sequestration potential of different forests, some scholars like Feyissa et al.[6], Melese et al.[18], Gedefaw et al. [7], Nega et al.[19], Chinasho et al.[4], and Abere et al. [1] have studied the carbon stock variation along altitudinal gradient of Edgu forest, Woody plants of Arba Minch ground water forest, Tara Gedam forest, Danaba community forest, Humbo forest, and Banja forest respectively. But no study has been conducted in Wacho forest and any of the above researchers didn't investigate the carbon stock variation of dead tree and dead wood carbon along altitudinal gradient of their study areas. On the other hand, this research investigated the carbon stock variation of Wacho forest by including the carbon pool of dead tree and dead wood carbon along altitudinal gradient of the study area. Therefore, this paper filled the 
deficient scientific quantitative data of carbon stock variation along altitudinal range of the forest as well as it filled the gap stated in the above researchers.

\section{Methods}

\section{Description of the Study Area}

The study area is located in Hawa Galan district, Kellem Wollega Zone, Oromia Region, Ethiopia. The forest covered 720 hectares (ha) of land and it is located at about $630 \mathrm{~km}$ to the South west of the capital city of Ethiopia, Addis Ababa and about $22 \mathrm{~km}$ to the town of Dambi Dollo. Geographically, it is found between $8^{\circ} 42^{\prime} 32^{\prime \prime} \mathrm{N}-8^{\circ} 42^{\prime} 34^{\prime \prime} \mathrm{N}$ and $40^{\circ} 52^{\prime} 49^{\prime \prime} \mathrm{E}-40^{\circ} 53^{\prime} 55^{\prime \prime} \mathrm{E}$ which is shown in figure (a).

Figure a: Location of the study area

The altitudinal range of the study area also ranges from 1435 to $1704 \mathrm{~m}$ above mean sea level. The mean maximum and minimum temperature of the study area was $30.84^{\circ} \mathrm{C}$ and $16.38^{\circ} \mathrm{C}$ respectively, and the mean annual rainfall was also $1,645 \mathrm{~mm}$, which is shown in figure (b).

Figure b: Maximum\& minimum temperature and mean rainfall of the study area

\section{Procedures of Data Collection}

\section{Delineation of the study area}

The boundaries of the study area were delineated by taking geographic coordinates through Geographical positioning system (GPS) at each turning point of the study area.

\section{Stratification of the study area}

Wacho forest was divided into stratum based on the relative homogenous unit of topography, which helps to form more or less homogeneous units of the forest to increase the efficiency and accuracy of the forest carbon accounting.

\section{Determine size and shape of sample plot}

About $400 \mathrm{~m}^{2}$ areas of square sample plot were employed for sampling of the study forest. Because square plot has a better probability to incorporate more of within plot heterogeneity and thus be more representative than the other shape of sample plots of the same area as indicated by Hairiah at al. [11].

\section{Determine sampling techniques and sample size}

Sample plots of $20 \mathrm{~m} \times 20 \mathrm{~m}$ were laid through systematic random sampling techniques to collect the required and relevant data of the study forest at every $200 \mathrm{~m}$ difference between each sample plot and $300 \mathrm{~m}$ difference between each transect line. Finally, a total of 73 sample plots were laid by using GPS instruments starting from the lower to the higher elevation of the forest figure (c).

Figure c: Location of sample plots along altitudinal gradient of the study area 


\section{Field Measurements}

\section{Sampling and identification of trees and shrubs}

According to Pearson et al. [20] all tree and shrub species having $\geq 5 \mathrm{~cm}$ diameter at breast height (DBH) were measured from $400 \mathrm{~m}^{2}$ areas of sample plots using diameter tape, and the height of those trees was also measured by using hypsometer. Woody plants having multiple stems at 1.3 meter were considered as a single tree and the largest stem was taken, while woody plants forked below 1.3 meter was treated as a single individual as indicated by Pearson et al.[20,21]. Plant identification was done at the National Herbarium of the Addis Ababa University using published volumes of Flora of Ethiopia and Eritrea.

\section{Sampling of dead trees and dead woods}

The samples of dead tree and dead wood were collected by using the principles of Goslee et al. [9] as follows.

Standing dead trees in class one which characterized by the existence of branches and twigs only having $\geq 5 \mathrm{~cm}$ DBH were measured from $400 \mathrm{~m}^{2}$ area of sample plots by using DBH tape and the height of those trees were measured by hypsometer. But the other types of standing dead trees with small and large branches only, trees with large branches only, and trees with bole only were measured its diameter at the base of the dead tree by using DBH tape and the height of those dead standing trees were measured by hypsometer. The lying dead woods, having $\geq 10 \mathrm{~cm}$ diameter were divided into sections of roughly one meter and the exact length and diameter at the middle of each section was recorded.

\section{Sampling of litters}

According to the principles of Pearson et al.[20] litter samples were collected manually from each of the five $1 \mathrm{~m} \times 1 \mathrm{~m}$ areas of subplots, which located at the four corners and one at the center of the main plot. About 100 grams of a composite sample was taken by mixing litter samples from each of the five sub plots of the main plot. Then it was placed in a plastic bag and labeled to which sample plot it belongs. Then after about 100 grams of 73 labeled composite samples were taken to the laboratory of Debrezeit horticoop Agricultural research center and the litter samples were oven dried to a constant weight at $105^{\circ} \mathrm{C}$ for 12 hours and the carbon fraction of litter samples were determined in the laboratory using Walkley-Black Method, 1934.

\section{Sampling of soil organic carbon and bulk density}

The samples of soil organic carbon (SOC) were collected by using the auger at a depth of $30 \mathrm{~cm}$ from each of the five $1 \mathrm{~m} \times 1 \mathrm{~m}$ areas of subplots, which located at the four corners and one at the center of the main plot. About 100 grams of a composite sample were taken by mixing soil samples from each of the five sub plots of the main plot. Then it was placed in a plastic bag and labeled to which sample plot it belongs. Then after about 100 grams of 73 labeled composite samples were taken to the laboratory of 
Addis Ababa Agricultural research center. Then the field moist soil samples were dried to a constant weight in an oven at $105^{\circ} \mathrm{C}$ for 12 hours and the percentage of organic carbon was determined in the laboratory using Walkley-Black Method, 1934.

The bulk densities (BD) of the soil samples were also collected by using a core sampler at a depth of $30 \mathrm{~cm}$ from each of the five $1 \mathrm{~m} \times 1 \mathrm{~m}$ areas of subplot pits, in which the samples of SOC were taken. The sub samples of $\mathrm{BD}$ were oven dried to a constant weight in an oven at $105^{\circ} \mathrm{C}$ for 24 hours to determine the oven dry weight of soil samples. The design of the main plot and subplot of the study samples is shown in figure $(\mathrm{d})$.

\section{Figure d: Design of the main plot and the subplots for field measurements}

\section{Estimation of Carbon Stocks}

\section{Estimation of above ground tree biomass and carbon stock}

The above ground biomass of trees and shrubs existed in the study area were calculated using the general allometric model of Chava et al.[3] as follows.

$\mathrm{AGB}=0.0673 \times\left(\rho \mathrm{DBH}^{2} \mathrm{H}\right)^{0.976} \ldots$

Where,

AGB- aboveground biomass (kg)

$\mathrm{DBH}-$ Diameter of trees at breast height $(\mathrm{cm})$

H- Height of tree (m)

$\rho-$ Wood density $=\left(0.6 \mathrm{ton} / \mathrm{m}^{3}\right)$, which is the average value of wood density of trees in Africa Henry et al.[12]

The above ground carbon and carbon dioxide equivalent sequestrated in above ground biomass of trees and shrubs found in the study area was calculated by the principles of Pearson et al. [20 \&21] respectively as follows.

Above ground carbon $(\mathrm{AGC})=$ Above ground biomass $\times 0.5 \ldots \ldots \ldots \ldots \ldots \ldots \ldots \ldots$ (eq.2)

The $\mathrm{CO}_{2}$ equivalent sequestered in the aboveground biomass=AGC $\times 3.67 \ldots \ldots \ldots$ (eq.3)

\section{Estimation of below ground tree biomass and carbon stocks}

Below ground biomass of trees and shrubs found in the study area was estimated by using root-shoot ratio factor of Mac Dicken [17]. According to Mac Dicken [17] and Pearson et al.[20], standard methods of estimating below ground biomass(BGB) and below ground carbon(BGC) can be obtained as $20 \%$ and $10 \%$ of above ground tree biomass respectively.

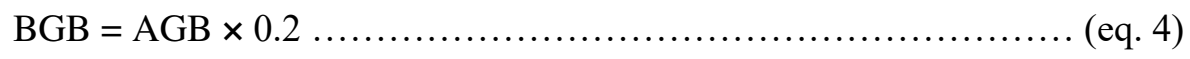

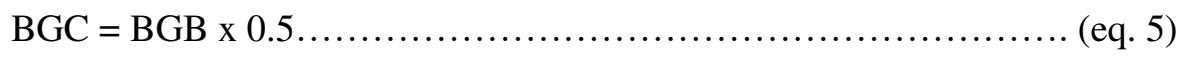

Where,

$\mathrm{BGB}=$ below ground biomass 
$\mathrm{BGC}=$ carbon content of below ground biomass and 0.2 is the conversion factor (or root -shoot ratio), which is $20 \%$ of the above ground biomass.

The amount of $\mathrm{CO}_{2}$ equivalent sequestrated in below ground biomass of the study area was calculated by multiplying BGC by the molecular mass ratio of carbon dioxide to Carbon (44/12) which is 3.67 as indicated by Pearson et al.[21].

\section{Estimation of dead tree and dead wood biomass \& carbon stock}

The biomass of standing dead trees which characterized by the presence of branches and twigs and the absence of leaves was calculated using the appropriate equations of Chave et al.[3] as biomass estimation techniques of live trees, but about $6 \%$ of the biomass of leave was subtracted as it recommended by Pearson et al.[20].

$\mathrm{SDWB}=0.0673 \times\left(\rho \mathrm{DBH}^{2} \mathrm{H}\right){ }^{0.976}(-6 \%)$------------------------------ (eq.6)

$\mathrm{SDWB}=$ Biomass of standing dead tree without leaves $(\mathrm{kg})$

$\mathrm{DBH}-$ Diameter of standing dead tree at breast height $(\mathrm{cm})$

$\mathrm{H}-$ Height of standing dead trees $(\mathrm{m})$

$\rho-$ Wood density $\left(0.5 \mathrm{~g} / \mathrm{cm}^{3}\right)$ as it suggested by Hairiah et al.[11]

The carbon stock of those standing dead trees was calculated by multiplying the standing dead tree biomass by 0.47 , which is the default carbon fraction of Intergovernmental panel on climate change(IPCC) [14]).

The biomass of standing dead tree, which characterized by the presence of small and large branches only, the presence of large branches only, and trees having trunk or bole only was calculated using the volume of the cone as it recommended by Goslee et al.[9]

$\operatorname{VOL}_{\text {cone }}\left(\mathrm{cm}^{3}\right)=\frac{1}{3} \times \pi \times \mathrm{h}(\mathrm{d} 1)^{2}---------------------------($ eq.7)

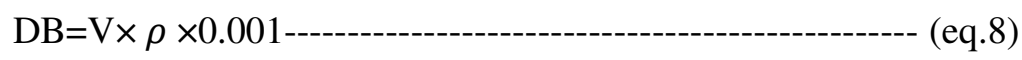

$\mathrm{VOL}_{\text {cone }}=$ volume of cone $\left(\mathrm{cm}^{3}\right)$

$\mathrm{h}=$ height $(\mathrm{cm})$,

$\mathrm{d} 1=$ diameter at the base of the tree $(\mathrm{cm})$

$\mathrm{DB}=$ dry biomass $(\mathrm{kg})$

$\rho=$ density of wood $\left(0.5 \mathrm{~g} / \mathrm{cm}^{3}\right)$ as it suggested by Hairiah et al.[11].

The carbon stock of those dead trees was calculated by multiplying the dry biomass of dead tree with 0.47, which is the default carbon fraction of IPCC [14].

The biomass of lying dead wood was also calculated by using the volume and density of wood as recommended by Pearson et al. [20].

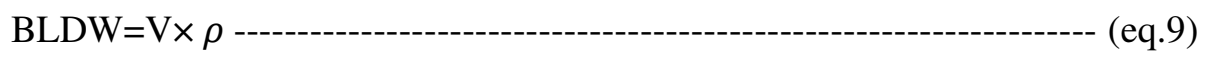

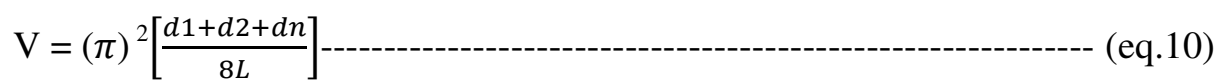


Where,

BLDW= biomass of lying dead wood

$\mathrm{V}=$ volume of lying dead woods $\left(\mathrm{m}^{3} / \mathrm{ha}\right)$

$\rho=$ density of the wood $\left(0.5 \mathrm{~g} / \mathrm{cm}^{3}\right)$ as suggested by Hairiah et al.[11].

$\mathrm{d} 1, \mathrm{~d} 2 \ldots . \mathrm{dn}=$ diameter of intersecting pieces of dead lying wood $(\mathrm{cm})$

$\mathrm{L}=$ length of the dead lying wood $(\mathrm{m})$

The carbon stock of those dead lying wood was calculated by multiplying the dry biomass of dead wood with 0.47 , which is the default carbon fraction of IPCC [14].

The total carbon stock of dead tree and dead wood was calculated by summing up all carbon stock of dead trees and dead woods as follows.

TDWC $=$ SDTC $1+$ SDTC2+DLWC

TDWC=Total carbon stock in dead tree and dead wood

SDTC1 $=$ Carbon stock of standing dead tree without leaves

SDTC2=Carbon stock of standing dead tree with small and large branches and without twigs, trees with large branches only, and trees with only bole

DLWC $=$ Carbon stock of dead lying wood

\section{Estimation of litter biomass and carbon stock}

The litter biomass found in the study area was calculated by the formula of Pearson et al. [20] as follow.

$\mathrm{LB}=\frac{\text { Wfield }}{A} * \frac{\text { Wsubsample }(\text { dry })}{\text { Wsubsample }(\text { fresh })} * \frac{1}{10,000} \ldots$

Where,

$\mathrm{LB}=$ Biomass of litter (t/ha)

W field=weight of a wet field sample of litter in gram from an area of $1 \mathrm{~m}^{2}$

$\mathrm{A}=$ size of the area in which litter samples was collected

W sub-sample (dry) =weight of the oven dry sub sample of litter taken to the laboratory to determine

moisture content

W sub-sample (fresh)=weight of the fresh sub sample of litter taken to the laboratory to determine the moisture content $(\mathrm{g})$

$\mathrm{CL}=\mathrm{LBM} \times \% \mathrm{C}$

Where,

$\mathrm{CL}=$ is total carbon stocks in the litter biomass (t/ha)

$\mathrm{LBM}=$ is oven-dry biomass of litter and $\% \mathrm{C}=$ carbon fraction of litter samples determined in the laboratory. 


\section{Estimation of soil organic carbon (SOC)}

The carbon stock density of soil organic carbon found in the study area was calculated using the volume and bulk density of soil as it recommended by Pearson et al. [21].

$\mathrm{V}=\mathrm{h} \times \pi \mathrm{r}^{2}$

Where,

$\mathrm{V}=$ volume of the soil in the core sampler $\left(\mathrm{cm}^{3}\right), \mathrm{h}=$ the height of core sampler $(\mathrm{cm}), \mathrm{r}=$ the radius of core sampler $(\mathrm{cm})$. Moreover the bulk density of soil sample was calculated as follows.

$B D=\frac{\text { Wav, dry }}{V}$

Where,

$\mathrm{BD}=$ soil bulk density $\left(\mathrm{g} / \mathrm{cm}^{3}\right)$, Wav, dry= average oven dry weight of soil sample per sample plot, and $\mathrm{V}=$ volume of soil sample in core sampler $\left(\mathrm{cm}^{3}\right)$.

$\mathrm{SOC}=\mathrm{BD} * \mathrm{~d} * \% \mathrm{C}$

Where,

$\mathrm{SOC}=$ soil organic carbon stock per unit area $(\mathrm{t} / \mathrm{ha}), \mathrm{BD}=$ soil bulk density $\left(\mathrm{g} / \mathrm{cm}^{3}\right), \mathrm{d}=$ the total depth at which the samples were taken $(30 \mathrm{~cm})$ and $\% \mathrm{C}=$ carbon fraction of soil samples, determined in the laboratory.

\section{Estimation of total carbon stock density}

The total carbon stock density of the study area was calculated by using the equation of Subuied et al.[23] by summing the carbon stock densities of the individual carbon pools of the study area.

$\mathrm{CT}=\mathrm{AGC}+\mathrm{BGC}+\mathrm{DTWC}+\mathrm{LC}+\mathrm{SOC}$ (eq.17)

Where,

$\mathrm{CT}=$ Carbon stock density for all carbon pools (t/ha)

$\mathrm{AGC}=$ Carbon stock in above ground tree and shrub biomass ( $\mathrm{t} / \mathrm{ha})$

$\mathrm{BGC}=$ Carbon stock in below ground tree and shrub biomass ( $\mathrm{t} / \mathrm{ha})$

DTWC $=$ Carbon stock in dead tree and dead wood biomass (t/ha)

$\mathrm{LC}=$ Carbon stock in litter biomass ( $\mathrm{t} / \mathrm{ha})$

$\mathrm{SOC}=$ Soil organic carbon $(\mathrm{t} / \mathrm{ha})$

\section{Data Analysis}

The collected data like DBH of live trees \& dead trees, height of live trees $\&$ dead trees, dry weight $\&$ carbon fraction of litter samples and soil samples were recorded on the Microsoft excel data sheet of 2007 and it was analyzed by using Statistical Package for social science (SPSS) software version 21. The relationships between different dependent variables (AGC, BGC, DTWC, LC and SOC) and independent variable (altitude) were processed and tasted by descriptive statistics and one way analysis of variance (ANOVA) at $95 \%$ of confidence interval. Descriptive statistics were used to summarize the mean carbon 
stock of each carbon pool of the study area, while one way ANOVA was used to determine the statistical significance difference of carbon stock along altitudinal gradient of the study area.

\section{Results}

There was a variation of mean carbon stock of each carbon pool along altitudinal gradient of Wacho forest, but it is not statistically significant at $95 \%$ of confidence interval except litter carbon stocks (table 1).

Table 1: Mean carbon stock of each carbon pool along altitudinal range of the study area

\begin{tabular}{llllll}
\hline $\begin{array}{l}\text { Altitudinal } \\
\text { class }\end{array}$ & AGC & BGC & DTWC & LC & SOC \\
\hline & & & & & \\
$1435-1560 \mathrm{~m}$ & $278.95 \pm 7.25$ & $55.77 \pm 1.48$ & $3.3 \pm 3.33$ & $2.13 \pm 0.62$ & $107.79 \pm 16.57$ \\
$1560.01-1643 \mathrm{~m}$ & $280.1 \pm 31.69$ & $56.02 \pm 6.34$ & $3.02 \pm 0.27$ & $1.80 \pm 0.31$ & $109.60 \pm 14.56$ \\
$1643.01-1704 \mathrm{~m}$ & $274.52 \pm 50.13$ & $54.84 \pm 9.97$ & $3.07 \pm 0.34$ & $1.70 \pm 0.4$ & $109.92 \pm 14.5$ \\
P-Value & 0.864 & 0.864 & 0.066 & 0.019 & 0.92 \\
F-Value & 0.146 & 0.146 & 2.835 & 4.222 & 0.083 \\
\hline
\end{tabular}

\section{Discussion}

\section{Carbon stock variation along altitudinal gradient of Wacho forest}

The mean carbon stock of each carbon pools was changed along altitudinal class of the study area. The largest mean above and below ground carbon stock was found in the second altitudinal class (1560.01$1643 \mathrm{~m})$ followed by the first altitudinal class $(1435-1560 \mathrm{~m})$, and the third altitudinal class $(1643.01$ $1704 \mathrm{~m}$ ) of the study area(table 1). This was due to the predominance of larger DBH and height of tree species at the second altitudinal class than the first and the third altitudinal class of the study area. Even though both the mean AGC and BGC were not evenly distributed along altitudinal class of the study area, their variations were not statistically significant at $\alpha=0.05(\mathrm{~F}=0.146, \mathrm{P}=0.864)$ (table 1$)$. The result was similar to the mean AGC and BGC stock distribution of Banja forest, that the largest mean AGC and BGC stock of Banja forest was reserved in the middle altitudinal class of the study area without a statistically significant mean differences of carbon stock at $\alpha=0.05(\mathrm{~F}=0.3765, \mathrm{P}=0.7935)$, that studied by Abere et al.[1].

The mean carbon stock of dead tree and dead wood was slightly varied in each altitudinal class of the study area. The largest mean dead tree and dead wood carbon stock was stored in the first altitudinal class followed by the third and the second altitudinal class of the study area(table 1). This might be due to 
the presence of higher human and livestock disturbances in the first altitudinal class than the other altitudinal class. But the variation of the mean dead tree and dead wood carbon stock distribution was not statistically significant along altitudinal class of the study area at $\alpha=0.05(\mathrm{~F}=2.835, \mathrm{P}=0.65)($ table 1$)$.

The largest mean LC stock was found in the first altitudinal class followed by the second and the third altitudinal class of the study area (table 1). This was due to the existence of open canopy of trees in the first altitudinal class of the study area, which favor the growth of understory vegetation, annual herbs and grasses. The variation of the mean LC stock distribution was statistically significant at $\alpha=0.05(F=4.222$, $\mathrm{P}=0.019)$ (table 1). The mean LC stock distribution of wacho forest was in line with the mean LC stock distribution of Tara Gedam forest, which studied by Gedefaw et al.[7]. The largest mean LC stock of Tara Gedam forest was existed in the first altitudinal class of the study area with statistically significant mean differences of carbon stock at $\alpha=0.05(\mathrm{~F}=3.222, \mathrm{P}=0.046)$.

The largest mean SOC was found in the third altitudinal class followed by the second and the first altitudinal class of the study area (table1). Because some part of the third altitudinal class of class of the study area was the place in which deposition of sediments due to soil erosion takes placed. Also, it might be due to soil type, soil depth, soil texture, tree cover and tree species, and degree of disturbance regime. But the variation of the mean SOC stock distribution was not statistically significant along altitudinal class of the study area at $\alpha=0.05(\mathrm{~F}=0.84, \mathrm{P}=0.920)$ as shown in (table 1). The mean SOC stock distribution of wacho forest was similar to the mean SOC stock distribution of Edgu forest, in which the largest mean SOC stock of Edgu forest was found in the upper altitudinal class followed by the middle and lower altitudinal class of the study area without statistically significant at $\alpha=0.05(\mathrm{~F}=1288, \mathrm{P}=$ 0.311)[6].

\section{Coclusion}

The carbon stock of different carbon pools such as above ground carbon, below ground carbon, dead tree and dead wood carbon, litter carbon and soil organic carbon were varied within the study area due to the variation of environmental gradient. The upper altitudinal class of the study area was high in soil organic carbon, while the middle altitudinal class of the study area was high both in above and below ground carbon stock. The lower altitudinal class of the study area was also high both in dead tree and dead wood carbon stock and litter carbon stock. Even though altitudinal gradient was the factor that affects the carbon stock distributions of the study area, the carbon stock variations were not statistically significant at $95 \%$ of confidence interval except litter carbon stock. So it was possible to conclude that; altitudinal gradient had not a statistically significant influence except litter carbon stock of Wacho forest.

\section{Abbreviations}


AGB: aboveground; AGB: Above ground biomass; AGC: Above ground carbon; ANOVA: analysis of variance; BD: Bulk Density; BGB: Below Ground Biomass; BGC: Below Ground Carbon; BLDW: Biomass of lying dead wood; CL: Total carbon stocks in the litter biomass; DBH: Diameter at Breast Height; DLWC: Carbon stock of dead lying wood; GPS: Geographical Positioning System; H: Height of tree; Ha: hectare; HGs: Greenhouse Gases; LB: Biomass of litter; LBM: Oven-dry biomass of litter : SDWB: Biomass of standing dead tree without leaves; SOC: Soil Organic Carbon; SPSS: Statistical Package for social science; TC: Total carbon; TDWC: Total carbon stock in dead tree and dead wood.

\section{Ethics approval and consent to participate}

Not applicable.

\section{Consent for publication}

Not applicable.

\section{Availability of data and materials}

Not applicable.

\section{Competing Interset}

The authors declare that they have no conflict of interest.

\section{Funding}

Not applicable.

\section{Authors' Contribution}

Gezahegn Gashu, GG, SD, ZF, and HA have collected the data. Gezahegn Gashu perform the experiment and analyzed the data and wrote the paper. All authors read and approved the final manuscript.

\section{Acknowledgments}

The authors are grateful to the Hawa Galan woreda agricultural office for their permission to carry out this research paper on Wacho Forest, and forest guards with experts at the district office for their support in field data collection.

\section{References}

1. Abere F., Belete Y., Kefyalew A., and Soromessa T. (2017). Carbon stock of Banja forest in Banja district, Amhara region, Ethiopia: An implication for climate change mitigation. Journal of Sustainable Forestry, 36(6), 604-622.

2. Bekele A. (1993). Useful Trees and Shrubs for Ethiopia: Identification, Propagation and Management for Agricultural and Pastoral Communities. RSCU/SIDA.

3. Chave, J., Rejou Méchain, M., Búrquez, A., Chidumayo, E., Colgan, M.S., Delitti, W.B., and Henry, M. (2014). Improved allometric models to estimate the aboveground biomass of tropical trees. Journal of Global change biology, 20(10), 3177-3190. 
4. Chinasho A., Soromessa T., and Bayable E. (2015). Carbon Stock in Woody Plants of Humbo Forest and its Variation along Altitudinal Gradients: The Case of Humbo District, Wolaita Zone, Southern Ethiopia. Journal of Environmental Protection and Policy, 3(4), 97-103.

5. FAO (Food and Agricultural Organization of the United Nations) (2005). The state of world's forests. Global Forest Resource Assessment. FAO forest paper 163, Rome, ITALY

6. Feyissa A., Soromessa T., and Argaw M. (2013). Forest carbon stocks and variations along altitudinal gradients of Egdu Forest and Implications of managing forests for climate change mitigation. Journal of Science, Technology and Art, 2(4), 40-46.

7. Gedefaw M., Soromessa T., and Belliethathan S. (2014). Forest carbon stocks in woody plants of Tara Gedam forest: Implication for climate change mitigation. Journal of Science, Technology and Arts, 3(1), 101-107.

8. Gibbs, H.K., Brown, S., Niles, J.O., and Foley, J.A. (2007) Monitoring and estimating tropicalforestcarbonstocks:makingREDD+reality.Environ.Res.lett.2,045023.http://dx.doi.org/10.1088 / 1748-9326/2/4/045023

9. Goslee, K., Walker, S.M., Grais, A., Murray, L., Brown, S., and Brown, S. (2015). Leaf technical guidance series for the development of a forest carbon monitoring system for REDD+. Winrock International Ecosystem Service. Arlington, USA, PP. 23-28.

10. Grace, J.(2004).Understanding and managing the global carbon cycle. Journal of Ecology, 92(2), 189202.

11. Hairiah, K., Sitompul, S.M., Van Noordwijk, M., and Palm, C. (2001). Methods for sampling of above and below ground carbon stocks. International Centre for Research in Agro forestry; Bogor, Indonesia.

12. Henry, M., Besnard, A., Asante, W.A., Eshun, J., Adu-Bredu, S., Valentini, R., and Saint André, L. (2010). Wood density, phytomass variations within and among trees, and allometric equations in a tropical rainforest of Africa. Journal of Forest Ecology and Management, 260(8), 1375-1388.

13. IPCC (Intergovernmental Panel on Climate Change) (2000). Land Use, Land-Use Change, and Forestry. Cambridge University Press, Cambridge, UK, pp. 996.

14. IPCC (Intergovernmental Panel on Climate Change) (2006).IPCC Guidelines for National Greenhouse Gas Inventories. National Greenhouse Gas Inventories Program, IGES, Japan.

15. IPCC (Intergovernmental Panel on Climate Change) (2007a).Summary for Policy makers. The Physical Science Basis. Contribution of Working Group I to the Fourth Assessment Report of the Intergovernmental Panel on Climate Change, Cambridge University Press, Cambridge, United Kingdom and New York, USA. 
16. Karki, S., Joshi, N.R., Udas, E., Adhikari, M.D., Sherpa, S., Kotru, R., and Ning, W. (2016). Assessment of forest carbon stock and carbon sequestration rates at the ICIMOD Knowledge Park at Godavari. ICIMOD Working Paper, (2016/6)

17. MacDicken, K.G. (1997). A guide to monitoring carbon storage in forestry and agro forestry projects in forest carbon monitoring program. Winrock International Institute for Agricultural Development, Arlington, Virginia.pp.87.

18. Melese B., Kelbessa E., and Soromessa T . (2014). Forest carbon stocks in woody plants of ArbaMinch ground water forest and its variations along environmental gradients. Journal of Science, Technology and Arts, 3(2), 141-147

19. Nega M., Soromessa T., and Bayable E. (2015). Carbon stock in Adaba-Dodola community forest of Danaba District, West-Arsi zone of Oromia Region, Ethiopia: An implication for climate change mitigation. Journal of Ecology and Natural Environment, 7(1), 14-22.

20. Pearson, T., Walker, S., and Brown, S. (2005). "Sourcebook for land use, land-use change and forestry projects."Winrock International and the Bio Carbon Fund of the World Bank. Arlington, USA. pp.57.

21. Pearson, T.R., Brown, S.L., Birdsey, R.A. (2007). Measurement guidelines for the sequestration of forest carbon: Northern Research Station, Department of Agriculture, Washington, D.C, pp.6-15

22. Stephens BB, Gurney KR, Tans PP, Sweeney C, Peters W, Bruhwiler L, Aoki S (2007). Weak northern and strong tropical land carbon uptake from vertical profiles of atmospheric CO2. Journal of Science, 316(5832), 1732-1735.

23. Subedi, B. P., Pandey, S. S., Pandey, A., Rana, E. B., Bhattarai, S., Banskota, T. R., and Tamrakar, R. (2010). Forest Carbon Stock Measurement: Guidelines for measuring carbon stocks in communitymanaged forests. Kathmandu: ANSAB, FECOFUN, ICIMOD.

24. Tesfaye S., Guyassa E., Joseph, R., Birhane, E., and Wondim, G.T. (2014). Land use and land cover change, and woody vegetation diversity in human driven landscape of Gilgel Tekeze Catchment, Northern Ethiopia. Journal of Forestry Research, 2014.

25. Yetebitu M., Zewdu E., and Sisay N. (2010.A review of Ethiopian Forest Resources: Current status and future management potions in view of access to carbon finances. Prepared for the Ethiopian climate research and networking and the United Nations Development Program. Addis Ababa, Ethiopia. 
Figures

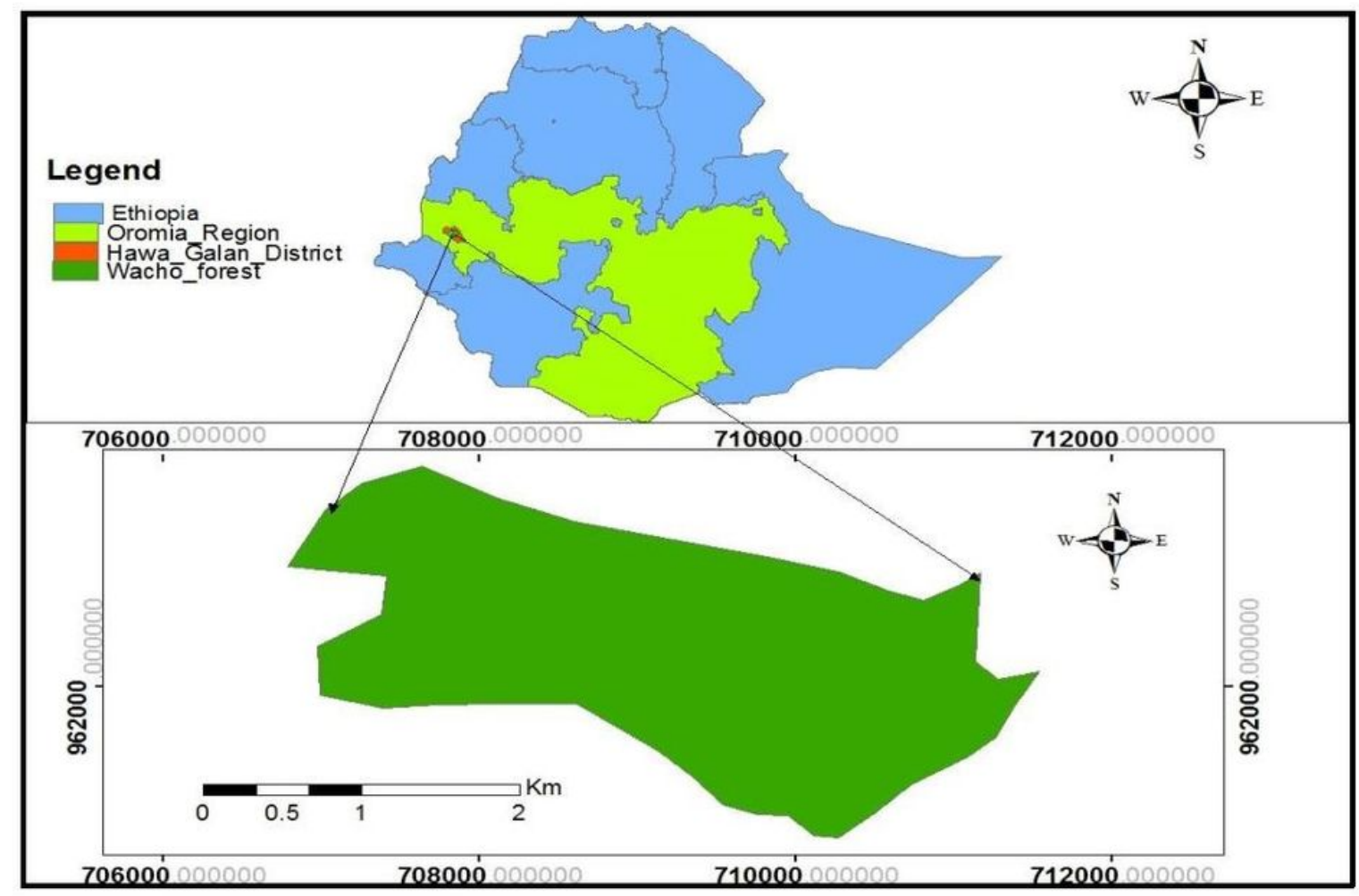

Figure a

\section{Figure 1}

Location of the study area 


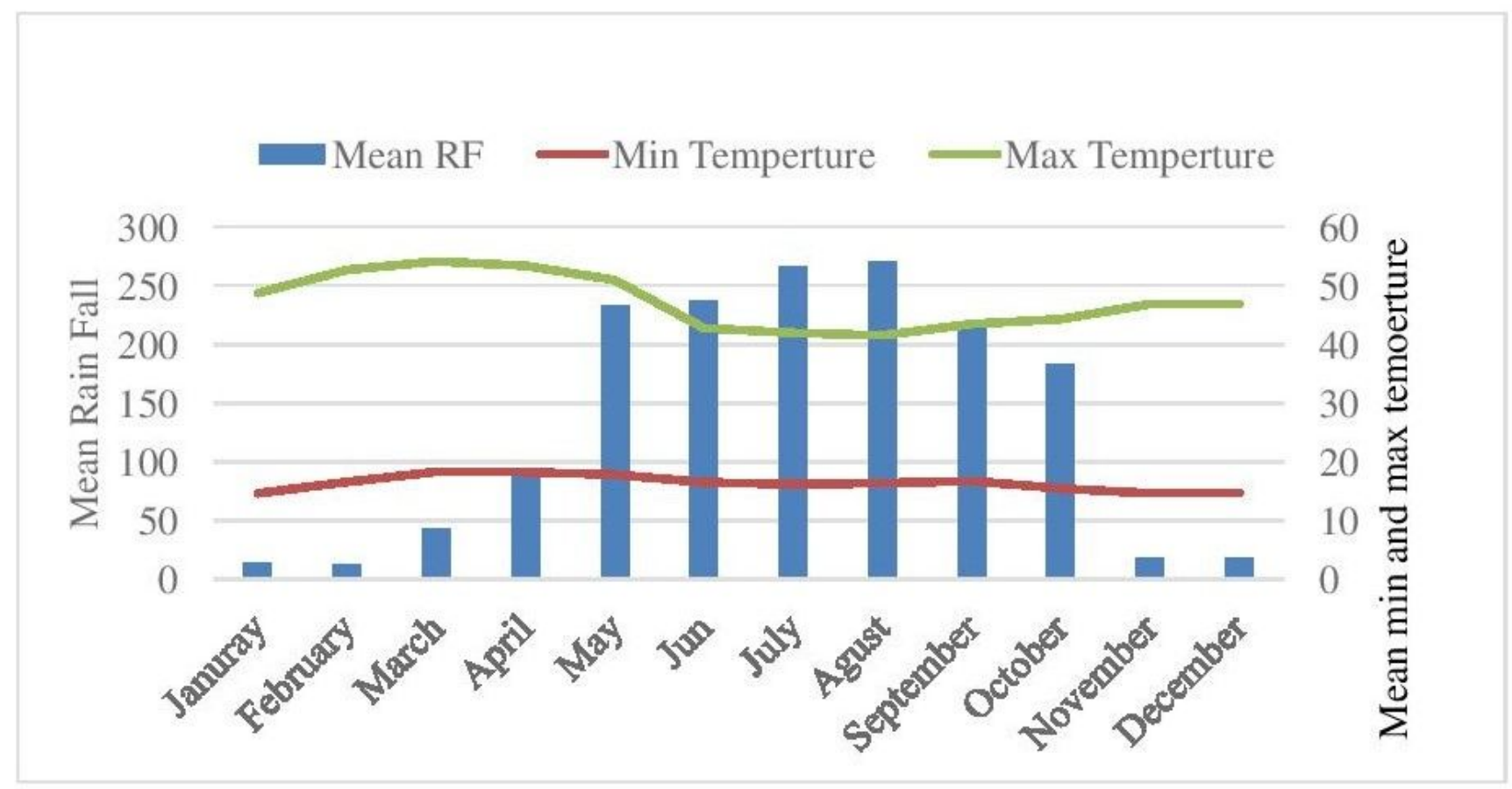

Figure $b$

Figure 2

Maximum\& minimum temperature and mean rainfall of the study area 


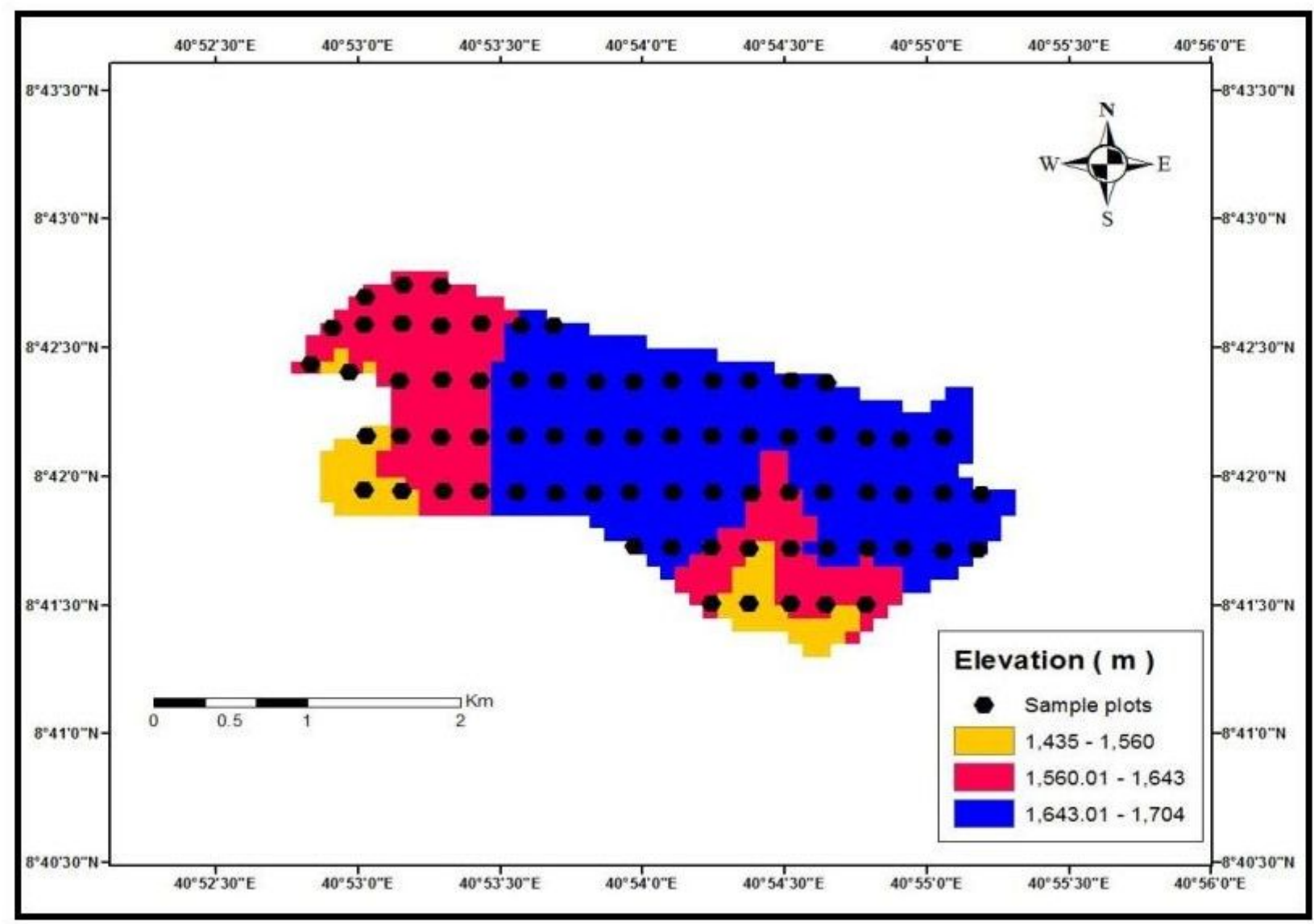

Figure c

Figure 3

Location of sample plots along altitudinal gradient of the study area 


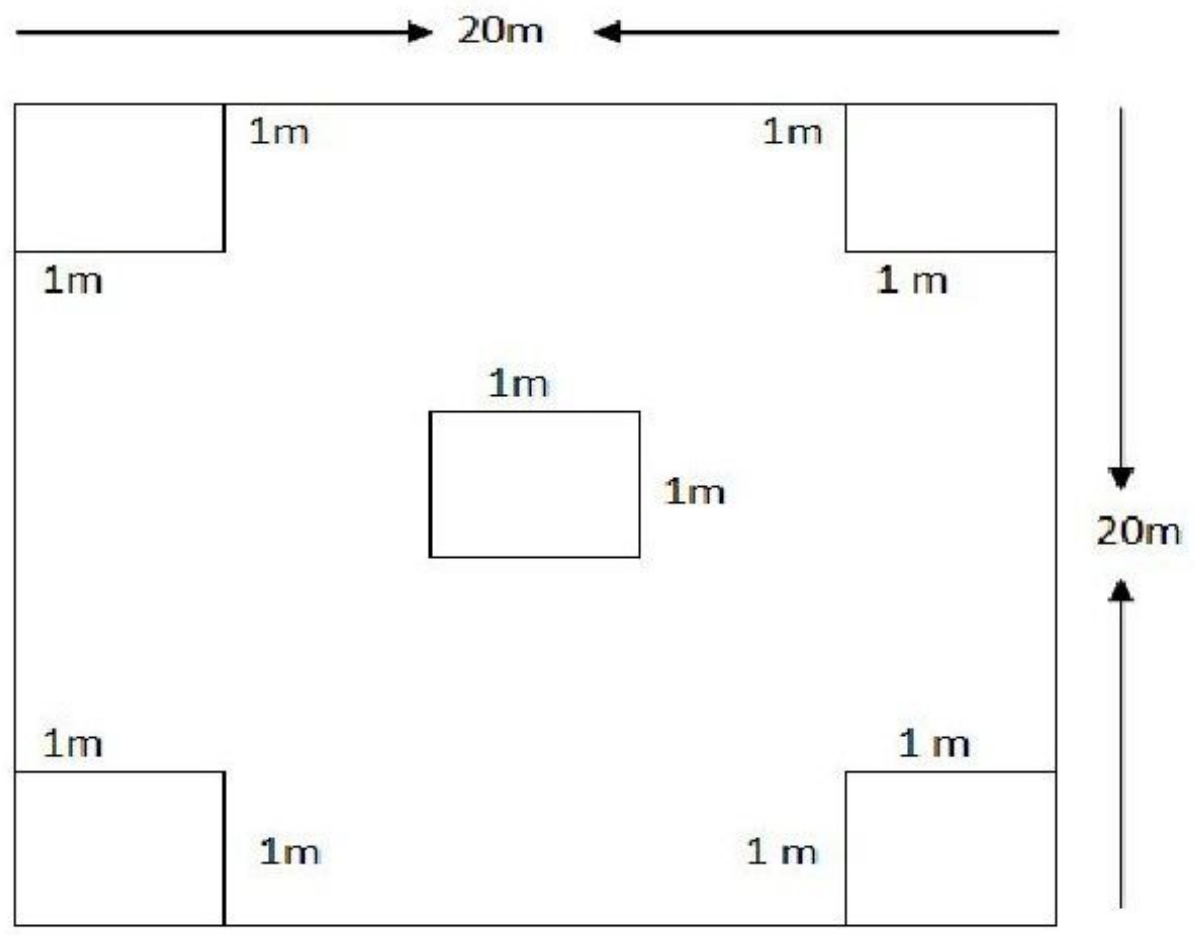

Key: $20 \mathrm{~m} \times 20 \mathrm{~m}=$ main plot and $1 \mathrm{~m} \times 1 \mathrm{~m}=$ sub plot

Figure d

Figure 4

Design of the main plot and the subplots for field measurements 